\title{
A Tale of Two Villages: Institutional Structure and Sustainable Community Organizations
}

\author{
Peter G. Gould \\ University of Pennsylvania Museum of Archaeology and Anthropology, USA
}

This paper describes the organizational features of community-controlled economic development ventures associated with heritage sites located in two contrasting rural communities, one in Ireland and the other in Belize. The paper demonstrates that sustainable community organizations share institutional governance features that reflect general principles previously identified by scholars of common pool resources and community heritage tourism projects. The paper argues that archaeologists or heritage specialists working with local communities to develop sustainable economic development projects are more likely to succeed if attention is paid to the establishment of appropriate governance institutions for the project that are rooted in local conditions but follow proven governance principles.

KEYWORDS community archaeology, governance institutions, common pool resources, economic development, sustainability

\section{Introduction}

As numerous papers in this volume demonstrate, many archaeologists are initiating projects to assist communities to realize economic benefits from nearby archaeological and heritage resources. A search of the literature reveals some examples of development projects relating to archaeology that have survived for many years (Davis, 20II; de Merode, et al., 2003; Gamarra, 20I0; Silverman, 2006). However, DíazAndreu's (2013: 232-34) recitation of failed projects in Latin America illustrates the conventional wisdom in the field that the globe is littered with failed field museums and community projects that have gone undocumented. The pressing question for archaeologists is: do insights exist into how better to do this work in a manner that can make archaeologists' efforts more successful?

This paper will address one potential response to that question, an answer inspired by literatures in economics, political science, and project evaluation. That literature suggests that archaeologists need to pay closer attention to the nature of the 
community institutions they create as they try to advance economic development. For the purpose of illustrating this issue, this paper will present data derived from my $\mathrm{PhD}$ research (Gould, 2OI4), examining the governance institutions of communitybased economic development projects in communities adjacent to archaeological sites. The data presented here are drawn from extensive qualitative and quantitative interviews with community leaders and project members and reviews of internal documents conducted in two such locations between 2010 and 2013.

The two communities described here, one in a small Irish village in County Clare and one in a small Maya village in central Belize, have little in common from the standpoint of history, culture, or community politics. Yet both are home to decadesold community projects rooted in environmental and archaeological heritage. These two village projects exhibit common characteristics that may inform the way archaeologists think about establishing and sustaining community-level development activities. The argument presented here is that commonalities in the nature of the governance institutions in these two community organizations, and the manner in which those institutions relate to local conditions, are important contributors to the sustainability of these organizations across several decades.

One project, the Burren Centre, is located in Kilfenora, a small village midway between Galway and Limerick on Ireland's western coast. Kilfenora is situated in a region known as 'The Burren', a limestone karst landscape that has been home to humans for more than 6000 years (Carthy, 20II). In 1972, a plan was launched in Kilfenora by local leaders and an outside adviser to establish a centre to interpret the unique environmental and archaeological heritage of the Burren for tourists. Today, the Burren Centre is the largest employer in the village and the reason that 25,000 to 30,000 tourists visit each year, helping to sustain the village's unusually collaborative culture even in the face of the recent Irish economic crisis (interviews with F. Connole, 8 March 20I2; J. Keane, 9 October 20II).

The village of Maya Centre, Belize presents a strong contrast. Situated on the entrance road to the Coxcomb Basin Wildlife Sanctuary, the approximately fifty households in Maya Centre are Mopan Maya families who moved to the area in the I970s after a dispute in a neighbouring village. Men in the community tend to leave the village during the day for work, generally in agriculture. Family disputes, religious differences, and political divides all contribute to a far less harmonious community than Kilfenora. Nonetheless, since 1987, a cross-section of the women in the community has coalesced around the Maya Centre Women's Group (MCWG), which sells traditional crafts produced by local families. It is a primary source of cash income to this community.

This paper tells the tale of the heritage-related projects in these two villages and the lessons to be gleaned from their success.

\section{Governance institutions, communities, and sustainability}

What is a governance institution? By 'institution', scholars of institutional economics mean what Douglass North has called 'the rules of the game' (I990: 4). These may be formal rules, laws, regulations, contracts, patents, or procedures enforced by entities such as the officers of organizations, bureaucracies, or even the courts. Alternatively, they may be informal rules such as traditions, taboos, and community 
compacts that are enforced through informal social structures such as ostracism, public shame, or other penalties. Institutional economists argue that institutions serve distinct purposes by reducing the 'transaction costs' (such as those to obtain information or to enforce agreements) and the risks of commercial relationships (Acheson, I994; Williamson, I998).

The ideas of institutional economists have been extended by scholars studying common pool resources, which are resources owned or controlled in common by a defined group. Examples are grazing lands, forests, fisheries, or irrigation systems managed on a community-wide basis. These scholars have examined the many examples of collaborative ventures that refute what Hardin (I968) famously termed the 'tragedy of the commons' and demonstrated that there are institutional commonalities in the way communities have self-organized to manage common pools (Ostrom, I990; Poteete, et al., 2010). Thus, governance institutions may be seen as the rules, traditions, and practices created to manage the affairs of a community project. Viewed in this light, community-based governance institutions must promote assurances of good faith, redress grievances, or otherwise enable individuals to engage in relationships requiring some degree of trust. Rules and regulations of community organizations, particularly those that engage in commercial transactions, serve an identical purpose.

'Community' is a critical notion in this conversation. Anderson (2006) has popularized the notion of 'imagined communities' that may be comprised of geographically dispersed groups sharing a common interest or groups coalescing around a notional commonality such as family, nationality, or a community of expertise such as 'heritage professionals' (Smith \& Waterton, 2009: II). From this perspective, every heritage site is inevitably a potential collision-ground for competing 'communities' and every community-based project engages a network of 'communities' with overlapping membership (Haggstrom, I983; Richards \& Hall, 2000; Shackel \& Chambers, 2004; Stonich, 2005; Sutton Jr, I983; see also Leventhal; Morris; Pyburn, this volume). Thus, from the standpoint of practical institution making, the community that matters is the complex and conflicted one that archaeologists find on the ground. Therefore, the word 'community', as used in this paper, simply means all of the residents who live in the vicinity of an archaeologist's project, whether or not they are a culturally homogenous group and whether or not individuals have competing traditional, religious, economic, or political claims on the heritage resources. Indeed, it is precisely the fact of those competing interests that compels a focus on the governance mechanisms through which the intra-community politics in economic development projects are played out at the local level.

Finally, what are 'sustainable' projects and institutions? In an environmental context, sustainability seeks to balance the demand for development from corporate and individual interests with the 'carrying capacity' of a resource. Carrying capacity, a biological concept, may be seen as 'the maximum number of a species that can be supported indefinitely by a particular habitat [...] without degradation of the environment and without diminishing the carrying capacity into the future' (Hardin, I977: II3). Carrying capacity has been extended to historical and cultural assets by scholars of the tourism industry, who use the concept to describe the conditions necessary to the preservation of the natural environment and the physical features of historic sites such as archaeological ruins (Murphy, I985). Numerous comprehensive 
definitions of sustainable development have been offered and even more indicators of sustainability proposed (see Kates, et al., 2005; Marshall \& Toffel, 2005). In this paper, however, following Ostrom (I990), the notion of 'sustainability' applied to these projects is simply their institutional survival across long stretches of time.

\section{The Burren Centre}

Running from Galway Bay nearly to the County Clare seat of Ennis, the Burren is a unique limestone karst environment where glacial activity millennia ago created an ecosystem in which alpine and Mediterranean plants grow side by side. Tillable soil is scarce but there is plenty of surface fodder for the beef and dairy cattle, sheep, and goats that give life to its economy. While the first clearly attributable archaeological remains in the Burren date from the Mesolithic, herders and farmers asserted a settled presence in this part of western Ireland in the warmer Neolithic period (Carthy, 2OII). Within a short span, they began to domesticate the rugged landscape and to construct the oldest artefacts remaining in the Burren, a collection of megalithic dolmen and tombs epitomized by the iconic portal tomb at Poulnabrone (c. $3200 \mathrm{BCE}$ ). By the sixth century CE, Christian churches appeared in the landscape; cathedrals, such as the one now ruined in Kilfenora, had their founding late in the first millennium, when local clans built stone ring forts and field walls to protect family and livestock (Carthy, 20II). One systematically examined ring fort, Caherconnell, has C-I4 dated artefacts to the seventh century CE and assigned structural remains to the late Neolithic or early Bronze Ages (Comber, 20I2). As one essayist of the region has noted, 'the Burren is more than just an open-air museum, it is an archaeologically saturated landscape' (Clements, 20II: 25).

Kilfenora is a former market town on the southern edge of the Burren. Residents frequently describe Kilfenora in the late I960s as 'derelict', citing seventeen or so abandoned houses in a village centre that even today numbers no more than about fifty structures, many newly built. This was also the time when the west of Ireland was at the early stages of an economic revival led by the growing importance to international air travel of nearby Shannon Airport. The Chairman of the Shannon Development Corporation, Brendan O'Reagan, saw development around the airport's free trade zone and tourism in Limerick's hinterland as potential offsets to the decline of rural communities in the region. In I969, village leaders asked O'Reagan for help and he dispatched a young associate, Brian Mooney, to Kilfenora.

There was a long tradition of community-funded, committee-led efforts to improve Kilfenora when Mooney arrived. When asked today, residents can name more than twenty voluntary organizations in this village of 463 people, each led by a volunteer committee. Mooney began in 1969 by organizing a series of educational lectures in Kilfenora while he met with local figures and slowly assembled a committee to manage a tourism project. Mooney encouraged the creation of an 'interpretive centre' for tourists to learn about the ecology and heritage of the Burren before setting off to discover it for themselves. His process was to engage community leaders, primarily from Kilfenora and pivotally including Kilfenora's parish priest and a 'village elder' (a local farmer), in an extended dialogue that culminated in the establishment of the Burren Centre (interview with B. Mooney, 7 March 20I2). 
The project was incorporated in 1975 as a for-profit cooperative of residents in three villages in County Clare (Connole, 2006). The idea was to construct the Centre on an abandoned site in the main square in Kilfenora and from there promote tourism throughout the Burren area. The Centre was financed by a grant from Bord Failte, an Irish tourism development authority, and from the proceeds of an offering of shares in the Burren Centre's parent organization to local residents. About 300 individuals, from the vast majority of households in Kilfenora, subscribed at least IR $£_{5}$ per share (some residents contributed much more, although each shareholder receives only one vote at business meetings). About 80 per cent of the shareholders lived in Kilfenora, while ro per cent were from each of two neighbouring villages.

The Centre, which opened in I975, housed a model of the Burren and other exhibits through which visitors were guided by local students. In I98I, two adjacent buildings were acquired and converted into tea-rooms to serve visitors and house a crafts shop. In its first decade, the cooperative launched a number of other projects, seeking to expand its economic development impact. These included ventures to produce fruit jams, peat firebricks, and wooden toys. By the early I980s all had failed due to poor planning and marketing or inattention to costs, with only the interpretive centre, tea shop, and craft sales businesses enduring commercially (IPC, I983).

From the early I990s until 2000, the Centre faced two related crises. First, in I99I, national government officials sought to situate a new interpretive centre adjacent to Mullaghmore Mountain in the heart of undeveloped Burren land, a location less than I5 km from Kilfenora. Burren Centre officials saw this proposal as potentially fatal to the Burren Centre. Fearful of alienating powerful government funders but in an uncertain economic situation itself, the Burren Centre's governing Committee opposed the Mullaghmore project but also sought a contingency funding arrangement. Other shareholders believed more aggressive and public opposition was essential. Ultimately, nearly 50 per cent of the shareholders turned out for a I99I Extraordinary General Meeting (EGM) to debate the strategy. After robust debate, the Committee's position prevailed by majority vote.

Subsequently, in I993, local business owners who were fearful that the Centre might founder in the wake of the Mullaghmore controversy sought to eliminate Article 5 of the centre's governing 'constitution', which precludes shareholders who are owners of competing local businesses (such as pubs or retail shops) from sitting on the Centre's governing Committee. Protagonists on each side differ regarding the others' motivations, but in interviews they are unanimous that their mutual concern was to ensure continued life for the Burren Centre itself. At a second EGM, in I993, Article 5 was retained by majority vote and competitors remain barred to this day from the Committee. The ten-year legal fight over the Mullaghmore centre, which was waged primarily by a group located in the nearby village of Kilnaboy on the road to Mullaghmore, finally ended in 2000 when the Irish Supreme Court quashed the Mullaghmore project. Shortly after, a new Irish government provided almost IR $£_{\mathrm{I}}$ million in funding to the Kilfenora centre to acquire additional land and construct an expanded interpretive centre, which opened in $200 \mathrm{I}$.

Formally, the Burren Centre is the primary activity of the Comhar Conradh na Boirne Teoranta (the 'Comhar'), an enterprise organized under Irish cooperative laws. Technically, the Comhar is a for-profit entity, though it has never declared a 
dividend. Co-ops are a traditional rural collective structure in Ireland, where a government entity, the Irish Cooperative Organisation Society, Ltd (ICOS), provides governance principles in the form of a model 'constitution'. The Burren Centre adopted the standard form ICOS constitution in 1975 , updated it in the I980s, and follows it to the letter.

Day-to-day operations of the Comhar are delegated to paid professional management under the supervision of a volunteer governing Committee whose members are nominated by other shareholders prior to the Annual General Meeting each year. The Committee, which has the authority to undertake most actions, is headed by a Chairman and includes a Vice Chair, Secretary, Treasurer, and occasional assistant officers, all chosen by the Committee itself. Quorums, voting procedures, eligibility to serve and the mechanisms for removing shareholders or Committee members are all stipulated in the constitution, as are requirements for an annual audit and the frequency of meetings. Additional policies are approved by the Committee. For example, in July I983 the Committee adopted a cycle for rotating its own membership and established limits for members to two consecutive three-year terms. Questions of interpretation of the constitution are resolved by the Committee or, in a dispute, may be arbitrated by ICOS. Decision-making at the centre is quite formal at Committee and shareholder meetings, with raised-hand voting reportedly common and, in at least one EGM, a secret ballot. The Committee of the Burren Centre has resisted changes to the constitution. Indeed, in the midst of the $200 \mathrm{I}$ construction project, the chairman at the time reached his six-year term limit. Committee members debated altering the rules to enable him to stay, but ultimately chose to abide by the constitution.

Albeit with some government assistance, the Burren Centre has been financially successful. The original display centre was built for IR $£ 26,000$ in 1975 with shareholder and government funding and volunteer labour from the village. In 20I0, the Comhar reported gross revenue of $€_{287,545}$ virtually identical to the prior year, of which $€ 87,79$ I represented a grant from the national government to employ the disadvantaged (interview with F. Connole, 8 March 20I2). Most of the centre's income comes from admission fees to the exhibit and from sales in the retail shop and tearooms. On a cash basis (pre-depreciation), the Comhar recorded a small profit in each of the five years ending in 20II. All cash and banking matters are managed by the Comhar's paid manager, although cheques must be signed by two Committee members.

This income supports a permanent staff of five and about thirteen seasonal workers, typically students from Kilfenora and neighbouring villages, making the Centre the village's largest employer. Financially, the Burren Centre is self-sufficient on an operating basis, but reliant on external support for major capital improvements and for some portion of the employment opportunities it offers. The village today has three pubs, two grocers, a youth hostel, a clothing store, and a crafts shop. In 20I2, nearly all residential and commercial structures in Kilfenora were occupied. Over the decades, the Burren Centre has directly spawned three other privately run tourist businesses in the region. In interviews, business owners unanimously confirm the importance of the Burren Centre to their businesses, 73.3 per cent of all community members interviewed said they or their family had benefited directly from the Centre, and all respondents agreed that Kilfenora would be 'worse off' were the Burren Centre to close. 


\section{The Maya Centre Women's Group}

A small section of the region known as the Cockscomb Basin in Belize was declared a National Forest Reserve/Jaguar Preserve on 2 December I984 - the first protected area devoted to the largest feline species in North America. The reserve was gradually extended until, in I995, the area - now known as the Cockscomb Basin Wildlife Sanctuary (CBWS) - encompassed $\mathrm{I22,000}$ acres, incorporating a vast range of rivers and valleys bounded by the Maya Mountains (BAS, 2008). Well inside the park lands, inaccessible to most visitors, are the ruins of a three small Maya archaeological sites.

In a pattern characteristic of archaeological and environmental reserves in Belize and elsewhere, the park was created as an exclusionary zone. Eleven Maya families living in a small village called Quam Bank on the CBWS lands were ordered to relocate immediately after 2 December I984, with several moving to the village of Maya Centre. Furthermore, existing residents of Maya Centre were ordered to abandon slash and burn farms on the park's perimeter and residents were banned from hunting on park grounds. Given those impacts, unless the local community could be motivated to restrain their incursions into the park and support conservation, the fledgling park was threatened by local resistance. This set the stage for the community-based preservation experiment to provide an alternative income source to the residents of Maya Centre, today a village of 400 persons in about fifty households that spans the entrance road to the CBWS (interview with E. Saqui, 27 May 20I3).

Virtually from its inception, the CBWS has been subject to a co-management arrangement with an environmental non-governmental organization, the Belize Audubon Society (BAS). The BAS first sought to garner support for the park by employing Maya Centre residents, ultimately retaining Ernesto Saqui, the village's only college graduate, as Park Superintendent with a staff of several wardens drawn from Maya Centre's small population. Coincidentally but importantly, Saqui also was Chairman of the Maya Centre Village Council.

After a false start in mid-I987, when village men walked out of an initial meeting in protest over the idea of a women's group, Saqui obtained agreement from the villagers later that year to create the Maya Centre Women's Group and construct a small building to sell traditional crafts made by MCWG members. Women were given the lead because most men left the village every day to find work, while most women stayed at home. Products included weavings, pottery, and slate carvings incorporating Maya calendars and other traditional motifs. For five years from I987, Saqui coached the group in accounting, business management, and problem-solving skills, contributing to the governance institutions of the Women's Group, before stepping back to leave the women to run the group (interview with E. Saqui, 9 June 20I3).

When an entrance charge to access Cockscomb was established in I988, the BAS authorized the Women's Group to sell tickets, offering the group Io per cent of the proceeds. A small thatched-roof building was erected in 1989 to house the group's wares at the intersection of the CBWS access road and the Southern Highway. Although a village dispute led to an arson fire at the cooperative building within a year of its construction, it was quickly rebuilt and within a few years twenty women were involved in the cooperative. In 2002, the thatched roof building was replaced 
with a larger cement structure that was financed by a $\mathrm{BZ} \$ 40,000(\mathrm{BZ} \$ 2=\mathrm{US} \$ \mathrm{I})$ grant

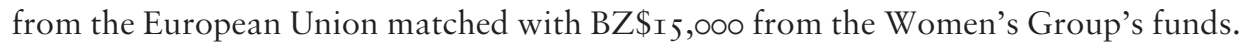
In 2009, the facility was expanded again with BZ\$30,000 from the Women's Group's funds to add a roadside restaurant building designed to support an eventual secondfloor expansion to include a small museum of Maya culture. The restaurant was outfitted through a grant from the European Commission, and the Young Men's and Women's Christian Association of Belize provided training in cooking and hospitality management to Women's Group members. By 2013, however, the restaurant had failed due, according to MCWG members interviewed, to the group's inability to manage the procurement of food and the operation of a restaurant.

The losses incurred by the MCWG related to the restaurant venture caused the group to cease dividend payments for three years and resulted in some loss of membership. In 2009, fifty-four women were members of the Women's Group, representing the large majority of the village's sixty-five households. By 2013 membership had fallen to forty members, the result of the restaurant failure, deaths, members who moved away, and two expulsions of members who started competing businesses. Nonetheless, the MCWG catered to about 9300 visitors to the CBWS in $20 \mathrm{I} 2$ (interview with D. Lizama, I4 June 20I3). In the twelve months ending in June 20I3, individual members of the Women's Group's received craft sales proceeds of about BZ\$ 20,000 and the MCWG earned over BZ\$29,000 in income in addition.

Tourist-related businesses have been lucrative for Maya Centre beyond the Women's Group. Two other households in the village have opened overnight facilities and small restaurants of modest quality but modest cost. Three retail stores service local and tourist requirements, two corn mills produce flour for the restaurants and local families, and three family-maintained crafts retail stores sell family-made items in competition with the cooperative. At least six village members maintain active businesses guiding CBWS visitors at a typical price of about BZ\$Ioo per visitor. One family of three guides estimated that they conducted I40 tours each year of two or more people, translating into about $\mathrm{BZ}_{\mathrm{I} 4}, \mathrm{O}, \mathrm{O}$ in income for those three families each year (interview with G. Chun, 25 January 20I0). According to Saqui, whose own family competes with the cooperative, spin-off businesses were part of his original vision, although the Women's Group resisted the creation of competing businesses when they first appeared.

The Women's Group is a central engine of the village's tourist economy. It is well supported within the village even by those families with competing businesses. It also has become a political force, integrating a village that otherwise is divided along family, religious, and political-party fault lines. The chairwoman is seen as one of the four leading figures of the village, along with the head of the Parent-Teacher Association for the village school, the head of the Water Board, and the Village Chairman. The Women's Group has been the recipient of grants, is the official partner of the BAS in ticketing, assists BAS to book the camp-style lodgings inside the park, and helps build demand for tour guides, taxis, and other services in Maya Centre. There is no food service at CBWS, so overnight campers must eat in Maya Centre or buy their food from local stores. Since a large proportion of the tour groups visiting Maya Centre are led by guides from nearby resorts on the Caribbean beaches, the Women's Group ensures that Maya Centre is not just another village one drives through on the way to a Belizean tourist attraction. 
The Maya Centre Women's Group is registered with the Belizean government as a Non-Governmental Organization. As noted above, the group has four sources of operating revenue. First, the Women's Group receives Io per cent of the price for every ticket to CBWS that is sold at their shop ( $\mathrm{BZ}$ \$ IO for foreigners, $\mathrm{BZ}$ \$2.50 for Belizeans; visitors also can purchase tickets at the sanctuary office). Second, craft sales are substantial and Io per cent of the revenue is retained by the MCWG. Third and fourth, the MCWG earns revenues from soft drink sales to tourists and corn milling services to local families.

Members must live in Maya Centre, but membership in the MCWG is not an automatic right. Upon reaching eighteen years of age, women may apply for membership, which is decided by majority vote of the members. Successful applicants must pay a $\mathrm{BZ} \$ 200$ 'initiation fee' to the group. The group has neither a written constitution nor by-laws, but new members sign a contract accepting the obligations of membership, violation of which can lead to expulsion. Among the most important rules are requirements that members not engage in competitive business activities, and a mandatory obligation to attend meetings, to work a specified number of volunteer shifts selling at the shop while wearing traditional Maya costume, and to participate in regular cleaning shifts at the MCWG building. A fine is levied on members who do not attend meetings or perform other duties.

The Women's Group is led by an unpaid executive committee of seven members. Every two years, ten members are nominated by the members to serve on the committee. Members elect seven individuals to serve on the committee in a raised-hand vote in an election supervised by a representative from the Belizean Women's Department. The individual with the most votes is named Chairlady, the second vote recipient is Vice Chairlady, and so on until all seven offices are filled in order of votes received. This system precludes divisive politicking in this disputatious village, as no individual 'runs' for a particular office; she must agree to serve in any capacity to which the group elects her.

The duties of the officers are substantial. Financial reconciliations are conducted at monthly meetings at which every member of the executive committee must be present to confirm the sales reports and the attribution of sales revenues to members. The Chairman and Treasurer are jointly responsible for the chequebook. Ticket sale proceeds are conveyed by two members of the committee to the bank in Dangriga, thirty minutes away by bus, and as many as four members may accompany when the MCWG's own revenues are deposited. Annual dividends are allocated by the executive committee based on seniority with the group. Major actions, such as grant applications, are overseen by the executive committee.

Members usually meet quarterly in a mandatory general meeting at which sale proceeds are dispersed, membership applications reviewed, and other business of the cooperative conducted. The Chairlady may call other meetings if required. Although no financial statements are prepared, all members are entitled to review and question the sales ledger book and the bank statements of the group at each quarterly meeting before distributions of proceeds are made. The cooperative does not compile regular financial statements, but it is clearly financially successful. In recent years, the cooperative has been able to accumulate $\mathrm{BZ} \$ 45,000$ to invest in their two buildingexpansion projects, typically pays a 'dividend' to members from its retained profits (although losses from the restaurant precluded payments from 2010 to 20I2), has 
periodically contributed funding to support the cost of a teacher's aide in the village school, has been able to make other charitable contributions to villagers, and always retains at least $\mathrm{BZ} \$ 7000$ in working capital.

\section{Institutional features}

The $\mathrm{PhD}$ research from which this case study has been drawn (Gould, 20I4) examined a broader array of institutional features that are relevant to these two organizations plus a third in Peru in the context of comparing those features to common pool resource theory. However, five of the common features of these two very different projects are highly relevant to archaeologists seeking to pursue economic development objectives at their sites. They are:

\section{Each project incorporates collective choice arrangements rooted in local conditions}

Both of these projects are democratically managed private enterprises. Shareholders of the Burren Centre elect the management committee and approve major corporate decisions at Annual General Meetings. Twenty per cent of the shareholders have the right to call Extraordinary General Meetings in the event of disputes. The management committee itself operates on majority vote principles. At Maya Centre, the cooperative's members elect officers for two-year terms and participate actively in the quarterly distribution meetings. All major decisions at the MCWG are made by majority vote of the members. The Burren Centre operates similarly to a traditional British corporation in a reasonably harmonious community. The MCWG, by contrast, has adopted a complex officer selection process, majoritarian decision-making, and financial transparency that are designed to minimize political stresses in a less harmonious setting. Both organizations, however disparate, are managed on democratic models.

\section{Institutional features of each group facilitate change and conflict resolution}

Through democratic procedures, significant changes have occurred in the mission and operations of both the Maya Centre and the Burren Centre co-ops. In each case, the governance rules of the organization encouraged the voicing of differing views while mitigating conflict by resolving differences through majoritarian procedures. Each has survived major internal challenges, the Mullaghmore-related debates in Ireland and the failure of the restaurant in Maya Centre, by relying on existing democratic mechanisms to manage disputes. Furthermore, electoral processes and term limits forestall the accumulation of power in one person or faction that would undermine the cohesion of the organization or inhibit the ability to take risks on new ideas.

\section{Each project provides meaningful economic value to the community}

The Maya Centre Women's Group directly provides significant cash income to all members through both proceeds from individuals' crafts sales and dividends from the profits of the MCWG itself. Spin-off benefits from the MCWG to the rest of the Maya Centre community are limited, since traffic through the village to the park would continue without the group's presence, but the sizable membership of the MCWG 
touches a large proportion of the fifty or so households in the village. The Burren Centre's economic impact is both direct and indirect. It is the largest employer in the village, but it also has generated a flow of visitors to the town who generate demand at local pubs, grocery stores, and shops that is fully acknowledged by shop owners. Finally, the Burren Centre stimulates tourist traffic elsewhere in the region. Support for each venture within the community very much reflects the widespread economic impact each has had. The economic benefits that derive from the projects provide important motivation to the participants to invest their time in sustaining the organizations.

\section{Each group was started with leadership from influential community members}

Even though the idea for the Burren Centre is attributed to an outsider, the initiative to bring him in and the leadership of the venture itself was entirely local. Moreover, a prominent Kilfenora farmer and the local priest are cited in interviews as being pivotal to acceptance by the broader community of the proposal to create the Burren Centre in Kilfenora. The parish priest was the group's first chairman. In Maya Centre, the village chairman initiated the Women's Group, managed local gender and family politics, and coached the members for five years. In this way he not only legitimized the project within the village and negotiated its complex politics, but also provided more sophisticated leadership to start the venture. In both cases, the influential local leaders who launched the projects eventually withdrew from active involvement.

\section{Outside funding and advice was provided in a 'light touch' mode}

Both of these ventures have benefited significantly from outside funding and operational advice, but neither has experienced efforts by outsiders to direct the activities of the venture. Funding has generally come without operational strings attached, leaving the members to manage their projects through internal processes. Where advice has been offered, it has been in the form of training or recommendations, not directives, and usually has not come from funding entities. Those who have assisted the members and leaders of the co-ops have done so without overruling the democratic and local management of the enterprise itself. Halstead (2003: I5), citing Brian Jones, has labelled this 'light touch adaptive management'.

The common features of these two projects are typical examples of those encountered in community-based common pool management regimes and in community-based sustainable tourism projects. Ostrom (I990; 2009) has described a more comprehensive list of common features of CPRs that includes points one, two, and four. All five points have been identified in various studies of sustainable tourism projects (Halstead, 2003; Jordan \& Duval, 2009; Long, 2008; Murphy \& Halstead, 2003; Murphy, I985; Newsham, 2004; Ngo, et al., 2008; Reeves, 2008; Winter, I998). Moreover, many of these same features arise in the World Bank's extensive review of its own local and community driven development projects over sixty years (BinswangerMkhize, et al., 2010). Even analyses supported by the Organization for Economic Cooperation and Development that focused more generally on decentralized, government-led development efforts have identified the necessity for similar structures at the local level if community-governed projects are to succeed (Greffe, 2005). 
Building on these previous studies, this review of the Burren Centre and the Maya Centre Women's Group lends support to the argument that, notwithstanding differences in social, cultural, and economic contexts, certain common institutional features can be associated with robust, long-surviving community-managed projects. The features identified in this paper, in particular, may be interpreted as enhancing trust and difference-bridging social capital (Putnam, 2000: 2I-24) among project participants, creating economic incentives for participants to invest time and resources to support the projects, and establishing mechanisms to enable change and resolve conflicts in a manner that facilitates risk-taking and mitigates potentially destructive differences among members.

Archaeologists seeking to pursue economic development projects at the local level should pay close attention to governance institutions. By supporting and encouraging, but not supplanting, the community's decision-making processes, by ensuring widespread economic benefits within the community, and by planning with community members to create governance structures that are robust in the face of change and conflict, archaeologists are more likely to create ventures that, like the Burren Centre or Maya Centre's Women's Group, prove sustainable for decades and not just for the few years excavation teams may be in town.

\section{Acknowledgements}

The author wishes to acknowledge helpful comments from Richard Hodges on an earlier draft of this paper and from the peer reviewers and editors of Public Archaeology.

\section{Bibliography}

Acheson, J. M. 1994. Transaction Costs and Business Strategies in a Mexican Indian Pueblo. In: J. M. Acheson, ed. Anthropology and Institutional Economics. Lanham, MD and London: University Press of America, pp. I43-65.

Anderson, B. 2006. Imagined Communities. London and New York: Verso.

Belize Audubon Society (BAS). 2008. Cockscomb Basin Wildlife Sanctuary [accessed 2 May 20I4]. Available at: $<$ http://www.belizeaudubon.org/protected_areas/cockscomb-basin-wildlife-sanctuary.html>.

Binswanger-Mkhize, H. P., de Regt, J. P., \& Spector, S. 2010. Local and Community Driven Development. Washington, DC: The World Bank.

Carthy, H. 20II. Burren Archaeology. Wilton, Ireland: The Collins Press.

Clements, P. 20II. Burren Country. Wilton, Ireland: The Collins Press.

Comber, M. 20I2. Caherconnell Archaeological Project Summary of Fieldwork to Date 20I2. Carron, Ireland: Burren Forts, Ltd.

Connole, F. 2006. Community Services Business Plan for the Burren Display Centre, Ltd. Kilfenora, Ireland: Comhar Conradh na Boirne Teoranta.

Davis, P. 20Ir. Ecomuseums: A Sense of Place. New York and London: Continuum International Publishing Group.

Díaz-Andreu, M. 20I3. Ethics and Archaeological Tourism in Latin America. International Journal of Historical Archaeology, I7: 225-44.

Gamarra, R. M. 2oro. Huacas de Moche: Arqueología y desarrollo comunitario. In: L. V. Alvarez, ed. Arqueología y Desarrollo: Experiencias y Posibilidades in el Perú. Trujillo, Peru: Ediciones SIAN de Luis Valle Alvarez, pp. I69-80. 
Gould, P. G. 20I4. Putting the Past to Work: Archaeology, Community and Economic Development. Unpublished $\mathrm{PhD}$ thesis, University College London. Available at: <http://discovery.ucl.ac.uk $>$.

Greffe, X. 2005. The Instruments of Good Governance. In: S. Giguère, ed. Local Governance and the Drivers of Growth. Paris: OECD Publications, pp. 39-88.

Haggstrom, W. C. 1983. The Psychological Implications of the Community Development Process. In: L. J. Cary, ed. Community Development as a Process. Columbia, MO: University of Missouri Press, pp. 84-II2.

Halstead, L. 2003. Making Community-Based Tourism Work: An Assessment of Factors Contributing to Successful Community-Owned Tourism Development in Caprivi, Namibia. Windhoek: Directorate of Environmental Affairs and Wildlife Integration for Livelihood Diversification.

Hardin, G. I968. The Tragedy of the Commons. Science, I62(3859): I243-48.

Hardin, G. 1977. Ethical Implications of Carrying Capacity. In: G. Hardin and J. Baden, eds. Managing the Commons. San Francisco: W. H. Freeman \& Co., pp. II2-25.

Irish Productivity Centre (IPC). 1983. Confidential Report to Combar Conradh na Boirne. Kilfenora, Ireland: Comhar Conradh na Boirne Teoranta.

Jordan, L. A. \& Duval, D. T. 2009. Heritage Management and Tourism in the Caribbean. In: D. J. Timothy \& G. P. Nyaupane, eds. Cultural Heritage and Tourism in the Developing World: A Regional Perspective. London and New York: Routledge, pp. I86-208.

Kates, R. W., Parris, T. M., \& Leiserowitz, A. A. 2005. What is Sustainable Development? Environment, 47(3): 8-2I.

Long, C. 2008. Heritage as Pro-Poor Tourism: The Case of Vieng Xay, Laos. In: R. Amoeda, S. Lira, C. Pinheiro, F. Pinheiro, and J. Pinheiro, eds. World Heritage and Sustainable Development. Barcelos, Portugal: Green Lines Institute for Sustainable Development, pp. 227-36.

Marshall, J. D. \& Toffel, W. M. 2005. Framing the Elusive Concept of Sustainability: A Sustainability Hierarchy. Environmental Science \& Technology, 39(5): 673-82.

de Merode, E., Smeets, R., \& Westrik, C. 2003. Linking Universal and Local Values: Managing a Sustainable Future for World Heritage. Paris: UNESCO World Heritage Centre.

Murphy, C. \& Halstead, L. 2003. 'The Person with the Idea for the Campsite is a Hero': Institutional Arrangements and Livelihood Change Regarding Community-Owned Tourism Enterprises in Namibia. Windhoek: Directorate of Environmental Affairs.

Murphy, P. E. 1985. Tourism: A Community Approach. New York: Methuen.

Newsham, A. 2004. Who's Involved in What? Participation in Natural Resource Management Institutions and 'Community based Tourism Enterprises' in Two Conservancies in Northwest Namibia. Windhoek: University of Namibia.

Ngo, M. H., Wong, Y. C., \& Heng, C. K. 2008. Examining Conservation Possibilities on Urban Heritage Environment - its User Relation in Hanoi, Vietnam. In: R. Amoeda, S. Lira, C. Pinheiro, F. Pinheiro, and J. Pinheiro, eds. World Heritage and Sustainable Development. Barcelos, Portugal: Green Lines Institute for Sustainable Development, pp. 259-70.

North, D. C. I990. Institutions, Institutional Change, and Economic Performance. Cambridge: Cambridge University Press.

Ostrom, E. 1990. Governing the Commons. Cambridge and New York: Cambridge University Press.

Ostrom, E. 2009. A General Framework for Analyzing Sustainability of Social-Ecological Systems. Science, $325(24): 4$ I9-422.

Poteete, A.R., Janssen, M.A. \& Ostrom, E. 20Io. Working Together: Collective Action, the Commons and Multiple Methods in Practice. Princeton, NJ: Princeton University Press.

Putnam, R. D. 2000. Bowling Alone. New York: Simon \& Schuster.

Reeves, K. 2008. Place, Community and Heritage Tourism in Luang Prabang: Conserving and Interpreting the Intangible Heritage and Built Environment of an Historical Cultural Landscape. In: R. Amoeda, S. Lira, C. Pinheiro, F. Pinheiro, and J. Pinheiro, eds. World Heritage and Sustainable Development. Barcelos, Portugal: Green Lines Institute for Sustainable Development, pp. 3II-I8.

Richards, G. \& Hall, D. 2000. The Community: A Sustainable Concept in Tourism Development? In: G. Richards and D. Hall, eds. Tourism and Sustainable Community Development. London: Routledge, pp. I-I4.

Shackel, P. A. \& Chambers, E. J. 2004. Places in Mind: Public Archaeology as Applied Anthropology. New York and London: Routledge. 
Silverman, H. 2006. Archaeological Site Museums in Latin America. Gainesville, FL: University Press of Florida. Smith, L. \& Waterton, E. 2009. Heritage, Community and Archaeology. London: Duckworth.

Stonich, S. C. 2005. Enhancing Community-Based Tourism Development and Conservation in the Western Caribbean. In: T. Wallace, ed. Tourism and Applied Anthropologists: Linking Theory and Practice. Berkeley, CA: University of California Press, pp. 77-86.

Sutton Jr, W. A. I983. The Sociological Implications of the Community Development Process. In: L. J. Cary, ed. Community Development as a Process. Columbia, MO: University of Missouri Press, pp. 57-83.

Williamson, O. 1998. The Institutions of Governance. The American Economic Review, 88(2): 75-79.

Winter, M. 1998. Decentralized Natural Resource Management in the Sahel: Overview and Analysis. London: International Institute for Environment and Development.

\section{Notes on contributor}

Peter G. Gould received his $\mathrm{PhD}$ in $20 \mathrm{I}_{4}$ from the Institute of Archaeology, University College London. He is a Consulting Scholar to the Penn Cultural Heritage Center of the University of Pennsylvania's Museum of Archaeology and Anthropology and an adjunct professor of archaeology at the American University of Rome. Previously, he has been chief executive or board chairman of numerous industrial and service companies in the United States and in Europe. In the I970s, he held the senior staff position at the US President's Council of Economic Advisers and was Deputy Assistant Secretary for Export Development at the US Department of Commerce. He has served on the boards of several non-profit organizations, including the Sustainable Preservation Initiative, and was for six years the chairman of the Zoological Society of Philadelphia.

Correspondence to: Peter Gould, 563 Warwick Road, Haddonfield, New Jersey, ○8०33, USA. Email: pgould8@gmail.com 